\title{
Progresso, Desenvolvimento Sustentável e abordagens diversas de desenvolvimento: uma sucinta revisão de literatura*
}

\section{Progress, Sustainable Development and Different Approaches to Development: a Brief Literature Review}

\author{
Marcelo Gustavo Aguilar CALEGARE** \\ Nelson da SILVA JÚNIOR ${ }^{* * *}$
}

\begin{abstract}
RESUMO
Fruto de revisão de literatura, o presente artigo tem por finalidade abordar a noção de Desenvolvimento Sustentável (DS) por meio de seus antecedentes, emergência, críticas e avanços, com o objetivo central de compreendermos a necessidade de novas concepções de desenvolvimento, não restritas à esfera econômica. Para tanto, apresentamos a noção de progresso com base das teorias econômicas e enfoques desenvolvimentistas do século XX, mostrando também o papel que estas atribuem ao ambiente. A partir do advento da crise socioambiental, nos anos 1970, destacamos teorias que buscaram integrar crescimento econômico, equidade social e harmonia ambiental, dando ênfase maior ao DS. Por fim, debate-se a redefinição de desenvolvimento segundo a ótica de Sen (2000), Viana (2007), Morin e Kern (2001) e Sachs $(1993,2002,2004)$. Discute-se que essa nova concepção deve focar o desenvolvimento do ser humano de modo global, o que significa o exercício pleno de direitos humanos, a expansão da liberdade, o envolvimento das pessoas com seus ecossistemas e na tomada de decisões, bem como a criação de condições de produção de meios de existência viáveis e em função de cada contexto socioambiental.
\end{abstract}

Palavras-chave: progresso; desenvolvimento sustentável; desenvolvimento.

\begin{abstract}
As the result of a literature review, this article aims to discuss the notion of Sustainable Development (SD) through its antecedents, emergency, criticism and advances. Our main objective is to comprehend the necessity of new development conceptions, not restricted to the economical sphere. To reach that scope, we present the notion of progress in the basis of economic theories and developmental approaches of the XX century. From the beginning of the socio-environmental crisis, in the 1970's, we point out to those theories which tried to integrate economic growth, social equity and environmental harmony,
\end{abstract}

\footnotetext{
"Agradecemos à CAPES, por concessão de bolsa de estudos para o primeiro autor que permitiu a realização desta pesquisa.

"* Doutor em Psicologia Social pelo IP-USP. Pesquisador visitante do LAPSEA/INPA. Email: mgacalegare@gmail.com

**** Doutor pela Universite de Paris VII. Professor Livre Docente do IP-USP. Email: nesj@terra.com.br
} 
giving more emphasis to the SD. Finally, we debate the redefinition of development according to Sen (2000), Viana (2007), Morin and Kern (2001) and Sachs (1993, 2002, 2004). We discuss that the new conception should focus on the human being development in a global sense, which means the exercise of full human rights, the expansion of liberty, the involvement of people with their ecosystems and the decision-making process, as well as the creation of conditions to produce means of existence that are possible and in accordance with each socio-environmental context.

Key-words: progress; sustainable development; development.

Se a ideia de progresso morrer no Ocidente, desaparecerá com ela muito do que prezamos há tempos, nesta civilização.

Robert Nisbet

Desde os anos 1970, a comunidade global vem refletindo com cada vez mais intensidade a respeito das condições de manutenção da vida humana na Terra. A crise socioambiental, colocada a partir da percepção de que o mundo é finito, em especial no que diz respeito aos recursos naturais disponíveis para o progresso e desenvolvimento da sociedade mundial, trouxe algumas questões: a humanidade vai continuar existindo se continuarmos nesse ritmo de destruição do planeta? Como aproveitar a tecnologia para usufruto adequado da natureza? Há alternativas para geração de energia a partir de recursos renováveis? É possível integrar bem-estar social, crescimento econômico e sustentabilidade ecológica? Qual o valor da extinção de plantas e animais? Que desenvolvimento queremos para a humanidade?

Atualmente, fala-se muito no Desenvolvimento Sustentável (DS) como um desafio a ser implantado pela sociedade global, de maneira que se equilibre o atendimento às necessidades de toda a população, tanto as gerações presentes como as futuras, com a conservação da natureza. Mas, o que é e quando surgiu a noção de DS? Este vem ao encontro de quê? Segundo Diegues (2001, p. 39), "esse termo transita pelos mais diversos círculos e grupos sociais, desde as organizações não governamentais até as de pesquisa, com notável e estranho consenso, como se fosse uma palavra mágica ou um fetiche". O autor afirma que uma análise mais profunda revela a falta de consenso, tanto pelo uso indiscriminado do adjetivo sustentável quanto pelo desgastado conceito de desenvolvimento.

Neste artigo, abordaremos a noção de DS por meio de seus antecedentes, emergência, críticas e avanços, com o objetivo de compreendermos a necessidade de novas concepções de desenvolvimento não restritas à esfera eco- nômica. Nesse percurso, trataremos da ideia de progresso subjacente aos enfoques desenvolvimentistas dos séculos XIX e XX, mostrando como a natureza é deixada em segundo plano em nome do avanço e do crescimento econômico. A partir dessas teorias desenvolvimentistas, apresentamos aquelas que passaram a se destacar, a partir dos anos 1960, por procurar integrar a visão ambientalista com crescimento econômico, equidade social e harmonia ambiental. Dentro deste subgrupo, em que estão o Ecodesenvolvimento, Economia Ecológica e Desenvolvimento Sustentável, daremos especial destaque ao DS. Por fim, discutem-se redefinições do que é o desenvolvimento segundo a ótica de Sen (2000), Viana (2007), Morin e Kern (2001) e Sachs (1993, 2002, 2004), cujas ponderações colocam a Amazônia no foco das atenções de novas estratégias de um desenvolvimento includente, sustentável e sustentado.

\section{Progresso e desenvolvimento}

Segundo Maimon (1993), a ideia de progresso está na base dos enfoques desenvolvimentistas tradicionais. Vejamos o motivo.

Para Bury (1921), o que permeia a ideia de progresso é o avanço da humanidade do passado, cuja condição original é primitiva, bárbara, nula, até o presente, cujos sinais são a sociedade, a cultura, a dominação da natureza. Nessa sequência, a humanidade continua avançando rumo a um futuro previsível de realização plena. Portanto, o progresso é o avanço/desenvolvimento de um estado inferior a outro superior

Na perspectiva da história da ideia de progresso de Nisbet (1985), esse avanço ou passagem do inferior ao superior encontra duas proposições intimamente relacionadas, desde os gregos até os "grandes profetas do progresso" dos séculos XIX e XX, Saint-Simon, Comte, Hegel, Marx, Spencer e Hayek: 
A) O progresso é a lenta, acumulativa e gradual melhoria do conhecimento (das artes e das ciências), expresso pela maneira do homem lidar com a natureza e consigo mesmo na convivência social. Há convicção de que a própria essência do conhecimento leva a progredir, melhorar, tornar mais perfeito.

B) Dada a condição moral e espiritual do homem na Terra, o progresso é o empreendimento da humanidade resultante de virtudes espirituais e morais (felicidade, independência nos tormentos da natureza e sociedade, serenidade e tranquilidade), levando a uma cada vez maior perfeição humana.

Comum às duas perspectivas encontra-se a referência de progresso em relação a alguma coisa: o progresso é da humanidade, que avança etapa por etapa (continuidade histórica), é cumulativo em conhecimento, cultura e moral e alcançará algum fim ou meta radiosa - a fé no retorno à idade de ouro.

Nisbet (1985) resume cinco premissas que permeiam a ideia de progresso: 1) crença no valor do passado, que serve de base cumulativa para o presente e o futuro; 2 ) convicção da nobreza e até mesmo da superioridade da civilização ocidental; 3) aceitação do valor do crescimento econômico e tecnológico; 4) fé na razão e no tipo de conhecimento científico e acadêmico que só pode derivar da razão; 5) fé na importância intrínseca e no inefável valor da vida neste mundo.

$\mathrm{O}$ autor descreve que o ápice da ideia de progresso aconteceu nos séculos XVIII e XIX, momento em que a ciência moderna, a secularização das ideias e o progresso econômico tornaram-se as chaves para a humanidade alcançar um determinado fim: liberdade, igualdade, justiça social, soberania popular. É a crença numa visão positiva e otimista de progresso para chegar a uma sociedade plenamente realizada.

Landes (1994) destaca que o crescimento econômico e avanços tecnológicos passam a ser aspectos centrais da busca do progresso com o advento da revolução industrial, a partir do século XVIII. Dentro dessa perspectiva, o progresso se traduz pela busca de riqueza por meio da industrialização e passa a ser sinônimo de desenvolvimento econômico, crescimento, avanço da tecnologia, inovação constante, expansão a novos mercados e aumento de produtividade. Como ressalta o autor, o crescimento econômico depende de inovações constantes e é a mola propulsora do processo de industrialização, por isso, sua substancial valorização até a atualidade. Pelo crivo do progresso, os países desenvolvidos são aqueles que atingiram certo grau de industrialização e abandonaram uma economia baseada fundamentalmente na agricultura. Os países subdesenvolvidos deveriam alcançar não só o mesmo nível de industrialização, mas de produção de bens e serviços, bem-estar, ética e valores.

Principalmente com o advento da revolução industrial, o desenvolvimento é adjetivado como econômico e designa progresso. Como resume Veiga (2006, p. 61), "desde meados do século XVIII, com a revolução industrial, a história da humanidade passou a ser quase inteiramente determinada pelo fenômeno do crescimento econômico". Os modelos clássicos de desenvolvimento/crescimento econômico estão baseados na crença de que a industrialização e os supostos inerentes a ela trariam progresso em todos os níveis às nações.

\section{O ambiente pelas ciências econômicas $\boldsymbol{e}$ enfoques desenvolvimentistas}

Maimon (1993) descreve que, nas teorias econômicas clássicas e neoclássicas dos séculos XIX e XX, o fator de produção, que impulsiona o desenvolvimento, está em função do capital, do trabalho e dos recursos naturais. O acento dado pelos teóricos é maior nos primeiros dois fatores. O terceiro é considerado como apêndice do sistema econômico e sua utilização seguia a equação: retirada de insumos do ambiente, passagem pelo sistema de produção, devolução dos dejetos.

Como nos mostra Veiga (2006), nas teorias das ciências econômicas o ambiente não é incorporado pelos economistas com peso equivalente às outras variáveis, nem considerado segundo uma dimensão sustentável, quando não completamente desconsiderado. Maimon (1993) aponta dois motivos para isso: a) a economia convencional concentra-se na escassez, isto é, entendem-se os bens ambientais como abundantes, livres e gratuitos. É o que Silva (2009) chama de "lógica do mundo vazio", isto é, as teorias foram formuladas num contexto onde havia pouca população, poucas máquinas, pouco capital e um mundo cheio de recursos a serem explorados; b) pelos bens ambientais serem públicos, não possuíam mercado definido e isso implicava na dificuldade de estimativa dos preços desses bens.

Em suma, dentro das teorias clássicas e neoclássicas da Economia, Maimon (1993) resume que o ambiente é considerado segundo três aspectos: a) fonte de matéria-prima, utilizada como insumo (renovável ou não) nos processos de 
produção; b) absorção de dejetos e efluentes da produção e do consumo de bens e serviços; c) outras funções, como suporte à vida animal, vegetal, lazer e estética.

Essa abordagem do ambiente pelas teorias econômicas está contida dentro dos enfoques desenvolvimentistas do século XX, imbuídos pelas ideias de progresso acima descritas. Maimon (1993) agrupa-os em quatro tipos:

A) desenvolvimento enquanto sinônimo de crescimento;

B) desenvolvimento enquanto etapa;

C) desenvolvimento enquanto processo de mudança estrutural;

D) desenvolvimento sustentável.

O primeiro e o segundo enfoques prevaleceram nos anos 1950 e 1960. Entendiam que a sociedade era constituída de unidades econômicas (de produção ou consumo), segundo processos mecanicistas e cujas leis são conhecidas cientificamente. O desenvolvimento se media pelo produto nacional bruto e renda per capita, sinais de eficiência econômica. Equidade social e distribuição dos frutos do crescimento econômico não são contempladas nestes modelos. Para desencadear o desenvolvimento, que significa passar de uma sociedade tradicional para uma moderna e implica em consumo de massa, os países devem seguir os modelos de industrialização.

Montibeller-Filho (2004) aponta que são recentes as críticas ao reducionismo econômico e desenvolvimentista sobre as teorias de desenvolvimento elaboradas, principalmente, nas décadas de 1950 e 1960 . O autor descreve três teorias de desenvolvimento econômico representativas de abordagens críticas ao sistema capitalista: a) a teoria da renda diferencial da terra, dos salários e dos lucros de David Ricardo; b) a teoria do fluxo circular de Joseph Schumpeter; c) a teoria marxista de crítica ao sistema capitalista. Em todas essas abordagens críticas, não estão contemplados componentes ambientais, como a degradação do meio pela poluição, destruição de ecossistemas e a exaustão de recursos naturais, renováveis ou não. Montibeller-Filho aponta também que apenas quando a atividade humana sobre a natureza atingiu níveis alarmantes, nos anos 1970, é que a consciência ambiental passou a ser pauta das discussões sobre as teorias de desenvolvimento.

No terceiro enfoque, a partir dos anos 1960, o desenvolvimento não é considerado como um processo mecânico, mas implica mudanças sociais e estruturais. Desenvolvimento e subdesenvolvimento são faces de um mesmo processo de divisão internacional do trabalho, isto é, o crescimento da produção e qualidade de vida em países centrais ocorre à custa dos países periféricos, mantendo-os atrasados. Por este enfoque, a industrialização também é a força motriz para romper o subdesenvolvimento. Diegues (2001) acrescenta que nessa linha foi proposta a teoria da dependência, que aponta interesses opostos entre países capitalistas centrais e periféricos.

O quarto enfoque, que tem raízes nos anos 1960 e permaneceu por um tempo sem grande destaque, pauta-se na integração entre crescimento econômico, equidade social e harmonia ambiental. Trata-se de abordagens que buscavam integrar a visão desenvolvimentista à ambientalista e resultaram na proposta do DS. Uma gama de vertentes teóricas foi elaborada segundo este enfoque:

1) Estratégias de ecodesenvolvimento. Anos 1970. Segundo Carvalho (2006), apresentadas por Maurice F. Strong no decorrer da $1^{\mathrm{a}}$ Reunião do Conselho Administrativo do Programa das Nações Unidas para o Meio Ambiente (PNUMA), em Genebra, 1973, para designar uma concepção alternativa de desenvolvimento e "que questionava o caráter tecnocrático do planejamento econômico tradicional, visando direcionar ações em zonas rurais dos países em desenvolvimento para incorporação da racionalidade de prudência ecológica" (NOGUEIRA; CHAVES, 2005, p. 133). Em 1974, Sachs desenvolve o conceito e essa versão aprimorada expressa um estilo de desenvolvimento aplicável também a projetos urbanos e orientado pela busca de autonomia e pela satisfação prioritária das necessidades básicas das populações envolvidas.

Nesse sentido, o ecodesenvolvimento é, segundo Sachs (1980, in: NOGUEIRA; CHAVES, 2005, p. 134), "desenvolvimento endógeno e dependendo de suas forças próprias, submetido à lógica das necessidades do conjunto da população, consciente de sua dimensão ecológica e buscando estabelecer uma relação de harmonia entre o homem e a natureza". Em outras palavras, esta proposta corresponde à preocupação de subordinar o desenvolvimento aos objetivos sociais e éticos, integrando as dificuldades ecológicas e buscando, no nível instrumental, soluções economicamente eficazes (SACHS, 1998). As estratégias do ecodesenvolvimento estão fundamentadas, segundo Godard (1997, p. 111, grifo do autor),

[...] no atendimento às necessidades fundamentais (habitação, alimentação, meios energéticos de preparação de alimentos, água, condições sanitárias, saúde e decisões nas participações) das populações menos favorecidas, 
prioritariamente nos países em desenvolvimento, na adaptação das tecnologias e dos modos de vida às potencialidades e dificuldades específicas de cada ecozona, na valorização dos resíduos e na organização da exploração dos recursos renováveis pela concepção de sistemas cíclicos de produção, sistematizando os ciclos ecológicos.

2) Bioeconomia ou Economia Ecológica. Anos 1980. Para Cavalcanti (1993, p. 86), “a economia ecológica busca é entender e integrar o estudo e o gerenciamento do 'lar da natureza' (a ecologia) e do 'lar da humanidade' (a economia), visando compreender a ecologia dos humanos e a economia da natureza". Silva (2009) precisa que a economia ecológica funda-se no princípio de que o sistema econômico é um subsistema dentro do ecossistema biofísico global, pois é deste que derivam a energia e matérias-primas para o próprio funcionamento da economia. Suas propostas partem da "lógica do mundo cheio", isto é, deve-se equilibrar o que já existe em abundância (população, capital, máquinas, tecnologia), de maneira a não comprometer o ambiente, já bastante explorado e com níveis de esgotamento. Para tanto, o desafio é reorientar políticas que ponderem:

a) escalas - quanto se pode mexer nos recursos naturais, na economia, na vida social etc.;

b) distribuição de renda, dos custos, dívida e pegada ecológica, para quem e onde;

c) eficiência - como o mercado se regula em função da definição dos outros dois princípios.

Por essa corrente, questiona-se a sustentabilidade do sistema econômico, por estar restrito pelas impossibilidades de reciclagem completa das matérias-primas devido ao fenômeno da entropia (segunda lei da termodinâmica): a parte da energia que não pode ser transformada em trabalho.

Leff (2006) aponta que os enfoques provenientes da lei da entropia para outras áreas adquirem um caráter heurístico, conectando seus significados científicos aos seus sentidos sociais em uma nova percepção da ordem ecológica e do processo econômico. Segundo a extrapolação do conceito a outros campos, a entropia é referida como energia que se dissipa/degrada e não pode mais ser utilizada, portanto, não é reciclável. Isso significa que, por essa lei da termodinâmica, se percebeu que há processos irreversíveis de utilização de energia por recursos não renováveis, o que leva necessariamente à degradação ambiental. Ou seja, a entropia surge como lei-limite que a natureza impõe à expansão do processo econômico.
3) O prolongamento da teoria neoclássica do equilíbrio e do crescimento econômico. Por meio destas teorias, são feitas análises sobre os regimes de exploração de recursos naturais não renováveis (DASGUPTA; HEAL, 1979; SOLOW, 1974, in: GODARD, 2002) ou renováveis (CLARK, 1973, 1990, in: GODARD, 2002) para identificar: a) as condições possíveis de uma exploração economicamente ideal;

b) as implicações sobre a evolução destes recursos;

c) deduzir as possíveis consequências analíticas para o estudo do crescimento e da distribuição do bem-estar.

Pelas proposições dos autores dessa classe de teoria, foram construídos modelos para analisar as implicações lógicas de uma exigência de equidade entre as gerações nas trajetórias de crescimento máximo, os respectivos níveis de consumo acessíveis a cada geração e as condições de transferência de custos de uma geração a outra (CHAVES et al., 2008).

4) Desenvolvimento sustentado. Nogueira e Chaves (2005) descrevem que, entre 1973 e 1986, pesquisadores do Centre International de Recherche sur l'Environnement et le Développement (CIRED) e Fondation Internacionale pour un Autre Développement (FIPAD) aprofundaram o debate sobre as estratégias de desenvolvimento ecologicamente viáveis e chegaram a essa proposta. Segundo este enfoque, é preciso construir um novo paradigma de desenvolvimento, que se sustente pela integração entre questões econômicas, sociais, culturais, ecológicas e tecnológicas. Este novo paradigma deve estar pautado:

a) na noção de prudência ecológica (princípio de precaução);

b) reformas no âmbito do processamento das políticas econômicas e sociais;

c) novas bases científicas que superem as limitações da ciência moderna;

d) novo arcabouço sociocultural de respeito à natureza.

5) Desenvolvimento Sustentável (DS). Segundo Diegues (2004), as ideias precursoras do DS surgem nos EUA, no final do século XIX, por meio das proposições conservacionistas de Gifford Pinchot, as quais enfocavam que a produção máxima sustentável pauta-se na busca de benefícios à maioria (incluindo as gerações futuras), pela redução dos dejetos e da ineficiência na exploração e consumo dos recursos naturais não renováveis. Dutra (2006) relata que a noção de DS foi originada em 1968, na 
primeira Biosphere Conference da UNESCO, em Paris. Para Veiga (2006), a expressão DS foi publicamente empregada pela primeira vez em agosto de 1979, em Estocolmo, no Simpósio das Nações Unidas sobre Inter-Relações entre Recursos, Ambiente e Desenvolvimento, no qual W. Burger apresentou o texto "A busca de padrões sustentáveis de desenvolvimento". Para Barbieri (2005), a expressão DS surge em 1980, no documento World Conservation Strategy (WCS), que menciona "um desenvolvimento que seja sustentável" (ALLEN, 1980, in: IBAMA/UNA, 2004, p. 11).

O termo DS só viria a ser mundialmente conhecido em 1987, pelo Relatório Brundtland, e popularizado pela Rio-92, sendo adotado por muitos organismos internacionais, nacionais, organizações não governamentais, entre inúmeras outras instituições - não obstante haja muita confusão em relação ao uso desse termo, especialmente devido às mais de 100 definições que adquiriu após sua ampla divulgação (BANERJEE, 2006). Segundo Godard (1997), a proposta de DS inaugurada pelo referido relatório não é inédita, mas inspirada em três correntes teóricas que já refletiam sobre a integração entre o desenvolvimento econômico e as consequências sobre o ambiente: as estratégias de ecodesenvolvimento, a economia ecológica e o prolongamento da teoria neoclássica do equilíbrio e do crescimento econômico. Vejamos a trajetória que culminou na emergência do DS e do que se trata.

\section{Do Desenvolvimento Sustentável (DS)}

$\mathrm{Na}$ perspectiva do Relatório PNUMA (IBAMA/ UMA, 2004), há uma trajetória no marco de referência do pensamento moderno em relação ao ambiente e ao desenvolvimento: nos anos 1950 e 1960, catástrofes ambientais e os primeiros trabalhos apontando problemáticas ambientais, como Primavera silenciosa, de Rachel Carson, em 1962, e A tragédia dos comuns, de Garrett Hardin, em 1968. Nos anos 1970, a fundação do ambientalismo moderno, em que se passa a integrar a visão desenvolvimentista com a ambientalista. Nos anos 1980, a definição do DS. Nos anos 1990, a implementação do DS nas agendas locais e globais. Do ano 2000 em diante, a revisão dessas agendas. Essa trajetória de discussões em nível internacional pode ser recapitulada de acordo com a seguinte sequência de eventos:

- 1968. Clube de Roma (Itália). Reunião entre cientistas de países desenvolvidos, com a publicação, em 1972, de Limites do crescimento (MEADOWS et al., 1978).
- 1971. Encontro preparatório de Founex (Suíça). Analisou-se a problemática da relação entre ambiente e desenvolvimento e foram traçadas as bases de um caminho intermediário entre as rejeitadas teses malthusianas e as cornucopianas.

A teoria de Malthus, do começo do século XIX, diz que as plantas e animais crescem em progressão aritmética, enquanto os homens crescem em progressão geométrica. A problemática existente entre superpopulação, produção de alimentos e incapacidade tecnológica para solucionar essa equação é a questão central de suas teorizações (FOSTER, 2005). As teses cornucopianas postulam a necessidade de ajuste tecnológico para superar a escassez física da produção do que precisamos para nossa existência, bem como o controle de poluentes decorrentes dessas atividades, uma vez que se entende ser essa a chave para desenvolver a capacidade ilimitada de produção de alimentos (SACHS, 1993).

- 1972. Estocolmo (Suécia). Conferência das Nações Unidas sobre Meio Ambiente Humano com o tema Meio Ambiente e Desenvolvimento. Produziu-se a Declaração de Estocolmo e criou-se o Programa das Nações Unidas para o Meio Ambiente (PNUMA).

- 1974. Cocoyoc (México). Simpósio Modelos de Utilização de Recursos, Meio Ambiente e Estratégias de Desenvolvimento, organizado pelo PNUMA e pela Conferência das Nações Unidas sobre Comércio e Desenvolvimento (UNCTAD). Produziu-se a Declaração de Cocoyoc.

- 1975. Relatório What Now (1975), da Fundação Dag Hammarskjöld. Menciona a adoção urgente de novo paradigma de desenvolvimento "endógeno (em oposição à transposição mimética de paradigmas alienígenas), autossuficiente (em vez de dependente), orientado para as necessidades (em lugar de direcionado pelo mercado), em harmonia com a natureza e aberto às mudanças institucionais" (SACHS, 2002, p. 54).

- 1980. Alguns documentos oficiais influentes: 1) do governo norte-americano, o Global 2000 (BARNEY, 1980), com previsões catastróficas para o ano 2000, devido ao modelo insustentável de desenvolvimento econômico; 2) o World Conservation Strategy (ALLEN, 1980); 3) os dois relatório da Brandt Comission (BRANDT, 1980, 1983), encabeçado pelo então presidente da Socialista Internacional, Willy Brandt. Como a interdependência entre desenvolvimento e ambiente se tornava cada vez mais óbvia, a Assembleia Geral da ONU adotou, em 1982, a Carta Mundial da Natureza, chamando a atenção para o 
valor intrínseco das espécies e do ecossistema (IBAMA/ UNA, 2004).

- De 1979 a 1987. O PNUMA, em conjunto com as Comissões Regionais das Nações Unidas, realizaram seminários sobre estilos alternativos de desenvolvimento, que culminaram no Relatório Brundtland, em 1987, denominado também Nosso futuro comum (CMMAD, 1991), cujo núcleo central é a formulação dos princípios do DS.

Criada em 1983, por decisão da Assembleia Geral da ONU, a Comissão Mundial sobre Meio Ambiente e Desenvolvimento (CMMAD) - ou Comissão Brundtland (em homenagem à presidente da comissão, a ministra norueguesa Gro Harlem Brundtland) - tinha como objetivo propor estratégias que aliassem desenvolvimento e ambiente, considerando a economia global de forma ampla. As análises se pautavam no seguinte viés: por um lado, existem dinâmicas econômicas que geram pobreza e desigualdade em países subdesenvolvidos, o que acentua a crise ambiental. Por outro lado, os padrões de produção e consumo de países desenvolvidos estão levando ao desgaste dos recursos naturais. A CMMAD produziu o Relatório Brundtland, que contém os princípios do DS. O Relatório (CMMAD, 1991, p. 46) define:

O Desenvolvimento Sustentável é aquele que atende às necessidades do presente sem comprometer a possibilidade de as gerações futuras atenderem a suas próprias necessidades. Ele contém dois conceitos-chave:

- o conceito de "necessidade", sobretudo as necessidades essenciais dos pobres do mundo, que devem receber a máxima prioridade;

- a noção das limitações que o estágio da tecnologia e da organização social impõe ao meio ambiente, impedindo-o de atender às necessidades presentes e futuras.

Portanto, ao se definirem os objetivos do desenvolvimento econômico e social, é preciso levar em conta sua sustentabilidade em todos os países - desenvolvidos ou em desenvolvimento, com economia de mercado ou de planejamento central. Haverá muitas interpretações, mas todas elas terão características comuns e devem derivar de um consenso quanto ao conceito básico de Desenvolvimento Sustentável e quanto a uma série de estratégias necessárias para sua conservação.

Essa definição é compartilhada por inúmeros órgãos internacionais, governamentais e não governamentais desde o Relatório. De acordo com Meunier e Freitas (2005), a ideia central do DS é a de gerar condições de desenvolvimento para crescimento das nações e erradicação das desigualdades e da pobreza, na qual a utilização dos recursos naturais seja conduzida de maneira a perdurar para as gerações futuras. O Relatório:

a) menciona as diferenças nos modelos de desenvolvimento dos países do Norte e Sul, insustentáveis em longo prazo;

b) introduz uma dimensão ética e política ao considerar o desenvolvimento como um processo de mudança social, que implica em transformações das relações econômicas e sociais entre os países;

c) enfatiza o processo democrático do acesso aos recursos naturais e distribuição dos benefícios do desenvolvimento;

d) propõe uma nova concepção de economia, que leve em conta variáveis ambientais, participação política e equilíbrio entre o uso de recursos e o crescimento demográfico;

e) qualifica melhor a crise ambiental em âmbito global;

f) menciona a insustentabilidade do desenvolvimento econômico capitalista às gerações futuras;

g) associa as questões socioambientais e a crise geral do capitalismo aos problemas socioeconômicos, pobreza, superpopulação e retardo do desenvolvimento nos países de periferia;

h) inverte o argumento: a preocupação passa a ser dos impactos da destruição do ambiente sobre o desenvolvimento econômico;

i) relaciona pobreza como causa e efeito dos problemas ambientais, fruto do modelo econômico vigente;

j) associa o inadequado uso e manejo de recursos naturais com desigualdades sociais e distribuição dos benefícios do desenvolvimento;

k) entrelaça desenvolvimento econômico às questões ambientais e sociais numa nova forma de desenvolvimento que seja sustentável.

- 1989. Painel Intergovernamental de Mudanças Climáticas (IPCC), criado pelo PNUMA e pela Organização Meteorológica Mundial (OMM) para avaliar cientificamente as mudanças climáticas. A respeito destas últimas, alguns protocolos foram elaborados pelas agências internacionais. Em 1987, o Protocolo de Montreal, em que os países signatários se comprometem a substituir as substâncias que empobrecem a camada de ozônio - especialmente os Hidroclorofluorcarbonos (HCFCs). Posteriormente, foi reforçado e ampliado por meio das emendas de Londres (1990), de 
Copenhague (1992), de Viena (1995), de Montreal (1997) e de Beijing (1999). Em 1997, o Protocolo de Kyoto, que entrou em vigor somente em 2005, estabelece a redução da emissão de gases de efeito-estufa. Com vigência até 2012, será substituído por novo documento, que atenda às indicações do IPCC.

- 1992. Conferência das Nações Unidas sobre Meio Ambiente e Desenvolvimento (CNUMAD) - conhecida como Rio-92 (ou Cúpula da Terra), que popularizou o DS. Os resultados foram:

1) reafirmação e ampliação da Declaração de Estocolmo, conhecida como Declaração do Rio de Janeiro sobre Meio Ambiente e o Desenvolvimento;

2) Convenção sobre Mudanças Climáticas;

3) Comissão de Desenvolvimento Sustentável;

4) Declaração de Princípios sobre Floresta;

5) Agenda 21;

6) acordo para negociar uma convenção mundial sobre a desertificação (criada posteriormente, em 1994);

7) Convenção da Diversidade Biológica (CBD). Um acordo suplementar à convenção foi firmado em 2000, chamado Protocolo de Cartagena sobre Biossegurança.

A Conferência das Partes (COP) é o órgão executivo das Convenções, trata de seus avanços e da sua implementação, bem como do espaço de deliberação das decisões de suas reuniões periódicas. A derradeira COP-16 ocorreu em Cancun (México), em 2010.

- 1997. Rio +5 (Nova Iorque). Avaliou-se que ainda faltavam muitas metas a serem alcançadas para concretizar a Agenda 21 e os objetivos do DS.

- 2000. Cúpula do Milênio das Nações Unidas. Elaborou-se a Declaração do Milênio, que reforça, dentre alguns temas, a necessidade do DS pelos países em desenvolvimento. Esta comporta também os oito Objetivos de Desenvolvimento do Milênio (ODM), a serem alcançados até 2015. Os 8 objetivos são:

1) erradicar a extrema pobreza e fome;

2) atingir o ensino básico universal;

3) promover a igualdade entre os sexos e a autonomia das mulheres;

4) reduzir a mortalidade na infância;

5) melhorar a saúde materna;

6) combater o HIV/AIDS, a malária e outras doenças;

7) garantir a sustentabilidade ambiental;

8) estabelecer uma parceria mundial para o desenvolvimento.
Para Cerqueira e Facchina (2005, p. 5), "a Agenda 21 e os ODM são dois instrumentos irmãos para a consecução do Desenvolvimento Sustentável".

-2002 . Rio +10 , Cúpula Mundial sobre Desenvolvimento Sustentável (ou $2^{\mathrm{a}}$ Cúpula da Terra). Johannesburgo. Discutiram-se os avanços da Agenda 21 desde a Rio-92. Verificaram-se poucos deles. Foram elaborados a Declaração de Johannesburgo e o Plano de Implementação de Johannesburgo, reafirmaram-se os compromissos da Declaração do Rio de Janeiro e do DS, com direcionamento às áreas que requerem maior esforço à sua implementação.

A importância dos eventos em Founex, Estocolmo, Cocoyoc, Rio de Janeiro, Johannesburgo e dos posteriores é que se passou a questionar que o desenvolvimento das nações - crescimento populacional, industrialização, produção de alimentos, poluição, consumo de recursos renováveis e não renováveis - levaria a Terra ao seu limite dentro dos próximos 100 anos (a contar dos anos 1970). A solução ainda está em discussão até hoje e se pondera, nos fóruns internacionais, nacionais e locais, qual a melhor maneira de conduzir o desenvolvimento e a preservação/conservação do planeta, nos diferentes níveis que isso representa. Existem muitas opiniões sobre que tipo de desenvolvimento é o melhor para a maioria dos países: há aqueles que defendem que a economia é o carro-chefe do progresso de qualquer país e, portanto, do mundo globalizado, enquanto outros preferem colocar a tríade econômico-social-ecológico para sustentar o desenvolvimento mundial.

\section{Críticas, limites e avanços do DS}

Muitas críticas foram feitas à noção de DS proposta desde o Relatório Brundtland. Nas linhas que seguem, apresentaremos grupos de argumentos dos muitos questionamentos feitos ao DS, apontando alguns avanços propiciados graças às discussões a respeito do tema.

Universalização de interesses sobre áreas estratégicas (crítica). Para Redclift (2006), o uso simplificado e aparente consenso do DS e sustentabilidade servem para camuflar as complexidades subliminares e as contradições de quem toma as decisões, a quem interessa tais decisões e com base no que elas são tomadas. A retórica do DS sustenta ações políticas e legitima determinados grupos, obscurecendo que as decisões são tomadas por alguns e colocadas como globais a todos. Sob o discurso de segurança humana e ambiental, há interesses econômicos e políticos dos países centrais. $\mathrm{O}$ ambiente é utilizado como recurso estratégico de 
dominação ideológica e a bandeira do ambientalismo global serve para dar aval a organismos supranacionais se sobreporem à soberania nacional de alguns países, especialmente aqueles que possuem grandes reservas de recursos naturais e diversidade biológica ainda não totalmente explorados.

Segundo Fernandes (2006), o modelo de DS expressa um projeto internacional de gestão de recursos naturais de áreas ecológicas importantes do planeta. O discurso consensual de preservação, que iguala interesses comuns entre os diferentes países, apaga as diferenças regionais e universaliza os interesses do Norte. Caberia ao Sul, prioritariamente, adotar as prerrogativas do DS, pois o modelo de desenvolvimento do Norte se mostrou insustentável. O DS serve como mecanismo de manutenção dos padrões de produção e consumo do Norte, que dita normas sobre o modo de preservação dos recursos naturais de áreas estratégicas para atender às demandas de crescimento econômico dos países hegemônicos.

Diferenças Norte/Sul (critica). Diegues (2001) critica que a proposta de DS ignora as relações de forças internacionais e obscurece: a) os interesses dos países industrializados em dificultar o acesso à tecnologia aos países em desenvolvimento; b) as relações desiguais de comércio; c) a oposição de multinacionais às propostas tecnológicas contrárias às suas estratégias globais. Além disso, Sachs (1993) aponta que os padrões de consumo do Norte são insustentáveis. Segundo dados da Organização para Cooperação Econômica e Desenvolvimento (OCED, 1991, in: SACHS, 1993), seus países membros respondem por parcela pequena da população mundial, concentram grande parte do capital, do comércio internacional e do consumo de energia e são responsáveis por grande parte da poluição do planeta. Apesar disso, tais países insistem na ideia de riscos ambientais globais e na responsabilidade compartilhada de enfrentá-los.

Explicitação das diferenças entre países do Norte e Sul (avanço). Como destaca Godard (1997), o futuro do ambiente depende da evolução dos conteúdos globais dos modos de desenvolvimento dos países de ambas as partes, sob diferentes aspectos: modos de consumo, escolha de tecnologias, organização do espaço, gestão dos recursos e dos resíduos. Desse modo, se deve respeitar as prioridades de desenvolvimento de cada parte, ao mesmo tempo em que se estabelecem compromissos globais para além dessas prioridades particulares.

Visão unilateral sobre a natureza (crítica). Para Banerjee (2006), a noção de DS tenta igualar custos ambientais e aponta responsabilidades como igualitárias, sem reconhecer diferenças entre localidades. Privilegia noções ocidentais de ambientalismo e preservacionismo, colocando a pobreza como causa da degradação ambiental nos países subdesenvolvidos. Transfere os direitos de povos e comunidades tradicionais a controladores nacionais e internacionais, sem considerar seus interesses particulares. As comunidades locais são tidas como objeto passivo do projeto ocidental de desenvolvimento, a despeito das promessas de autonomia local. Apesar de afirmar a aceitação da pluralidade, o DS baseia-se num sistema único de conhecimento, que coopta e desconsidera conhecimentos tradicionais ambientais sob o discurso da biodiversidade, biotecnologia e direitos à propriedade intelectual. A condução do DS acontece em função do modo de produção capitalista e da dinâmica dos mercados globais, com ferramentas consideradas eficientes para a superação da contradição entre sustentabilidade e capitalismo.

Inconsistência científica (crítica). Na Agenda 21, coloca-se que o conhecimento científico deve ser aplicado para articular e dar suporte ao DS, dando-lhe bases científicas seguras. No entanto, Banerjee (2006) aponta que não se explicita como operacionalizar essa cooperação científica, já que existem divergências entre cientistas do Norte e do Sul. Além disso, prioriza-se a ciência moderna ocidental e se descartam outras formas de conhecimentos não científicos, o que denota a falta de abertura aos conhecimentos tradicionais e se obscurecem as desigualdades e distinções culturais daqueles que cercam os recursos ambientais.

Para Redclift (2006), poucas disciplinas conseguem contribuir com as ligações entre o sistema ambiental humano e o natural, tal como identificado na Agenda 21. Isso indica que o manejo da natureza e dos recursos naturais está mais ligado às questões da necessidade e valores humanos de alguns grupos do que à sua comprovação científica. Nesse sentido, Carvalho (2006) aponta que o DS é noção sem método, uma vez que não possui método científico convincente que oriente as visões fragmentárias das ciências ambientais, sociais, econômicas etc. Não há teoria geral de uma ciência socioambiental que faça boa leitura das questões socioambientais, que exponha sobre a relação sociedade/natureza ou, ainda, que permita a integração entre as diferentes dimensões de sustentabilidade e, com isso, proponha soluções metodologicamente adequadas.

Reconfiguração da ciência (avanço). Por ser uma noção incerta e encontrar-se no cruzamento de várias tradições intelectuais, que buscam conciliar desenvolvimento 
econômico, proteção ao ambiente e equidade social, a discussão sobre o DS favoreceu a abertura para aproximações intelectuais, recomposições teóricas e reorganizações institucionais (CHAVES; RODRIGUES, 2006).

Além disso, as questões socioambientais não são compreensíveis por apenas uma disciplina ou ponto de vista científico. Uma visão mais ampla e melhor articulada, que dê conta da abrangência dessa problemática, só é possível pelo rompimento da fragmentação disciplinar, dos paradigmas científicos modernos e pela busca da inter/ transdisciplinaridade (FAZENDA, 2007, 2008; JAPIASSU, 2006), do pensamento complexo (MORIN, 2000, 2008), da pluralidade e diversidade epistemológica (SANTOS, 2008), da epistemologia e racionalidade ambiental (LEFF, 2002, 2006).

Decisões políticas (avanço). O conhecimento científico sobre a dinâmica dos processos biofísicos ainda é insuficiente e nem se consegue prever com precisão, em médio e longo prazos, os impactos de determinadas ações econômicas. Portanto, se pondera que decisões políticas talvez sejam o caminho mais prudente, neste momento, para manutenção da vida terrena. Segundo Chaves e Rodrigues (2006), tais decisões devem ponderar: a) um comportamento de segurança e de prevenção dos riscos conhecidos; b) a otimização do tempo para conhecer os fenômenos, para responder de forma mais eficaz aos problemas ainda incertos neste campo; c) a busca por soluções de menor arrependimento, que atendam de forma simultânea os vários objetivos da coletividade.

Nessa linha, fala-se no "Princípio de Precaução", cujas exigências de provas científicas (comprovação de determinados fenômenos) não são a única fonte para tomada de decisões que garantam a preservação ambiental. Entretanto, nos lembra Godard (1997, p. 109) que "conceitos e doutrinas, regras e procedimentos práticos vão ser elaborados de acordo com a conveniência das decisões econômicas, das regras jurídicas e das inovações institucionais".

Supremacia do econômico (crítica). Para Carvalho (2006), o DS é uma noção sem teoria, pois quer designar uma ação educadora do Estado sobre a sociedade de modo a-histórico e sem "análise crítica de como viabilizá-la num mundo real dividido e dominado pelo hegemônico modo de produção capitalista contemporâneo" (CARVALHO, 2006, p. 206).

De acordo com Banerjee (2006), Brito (1999), Diegues (2001), Montibeller-Filho (2004) e Santos (2008), o DS não representa uma mudança de paradigma em relação aos enfoques desenvolvimentistas das teorias econômicas clássicas e neoclássicas. Como vimos, estas têm intrínsecas a ideia de infinitude e estratégias corretas para o perpétuo crescimento, considerando os problemas ambientais como meras externalidades do processo de desenvolvimento e resolúveis pelas forças de mercado. Em outras palavras, a proposta do DS não está embasada numa nova teoria de desenvolvimento econômico sustentável e continua com a centralidade/universalidade do caráter sustentado da economia.

Para Marin e Castro (2006), o discurso globalizado e institucionalizado do DS está atrelado ao seu poder enunciativo, autoexplicativo, prenúncio de venturas e esperanças. $\mathrm{O}$ DS serve para fazer o desenvolvimento econômico aparecer como necessário, acalmando os medos provocados pelos seus efeitos indesejáveis. Nesse sentido, as críticas ao DS são à modernidade, pois revelam os problemas com os quais a sociedade atualmente se debate: da falência da solidariedade social e autodeterminação dos povos à destruição da natureza, por meio de uma racionalidade que se forja no avanço da civilização ocidental. Para as autoras, um dos desafios teóricos que se impõe é superar os mitos da terra prometida, da natureza sem limite e do paraíso ligados à ideia de progresso e modernidade, que permeiam o imaginário social e os discursos políticos, militares, científicos etc.

Integração de políticas ambientais e desenvolvimento econômico (avanço). Chaves e Rodrigues (2006) indicam duas posições predominantes: 1) os que acreditam que as taxas elevadas de crescimento podem financiar políticas ambientais rigorosas, centradas na difusão rápida de inovações, custos de manutenção/restauração de ambientes e mecanismos de reciclagem de materiais ou eliminação de dejetos; 2) aqueles cuja crença na harmonização entre desenvolvimento e preservação ambiental exige uma nova concepção de modelos de desenvolvimento, o que implica em mudanças significativas nos modos de vida, modos de produção, opções técnicas e formas de organização social e das relações internacionais. Apesar dos conflitos políticos entre setores ambientalistas e desenvolvimentistas, hoje já se tenta integrar essas duas vertentes em uma única direção.

Não equidade social (crítica). A noção de DS não explica como a sustentabilidade, as necessidades humanas e a preocupação com as gerações futuras podem ser operacionalizadas. O discurso de equidade, democracia e inclusão serve para justificar processos de modernização que não questionam a "capitalização, expropriação, mercadorização e homogeneização da natureza" (BANERJEE, 
2006, p. 94). Segundo Fernandes (2006), o DS não consegue corrigir a disparidade de riqueza entre as nações, não indica caminhos de superação da lógica que produz a pobreza, não atende nem mesmo as necessidades da geração presente, não relaciona coerentemente os problemas ambientais com os sociais e nem apresenta um novo projeto societário que, de fato, traga equidade social, prudência ecológica e sustentabilidade econômica.

Nessa linha, Veiga (2006) acrescenta que as teorias econômicas não têm poder de previsão em médio e longo prazos: a equidade na noção de DS vem atender os interesses de grupos específicos na atualidade e camufla o caráter fictício da previsibilidade das mesmas condições do presente para gerações futuras.

Avanço epistemológico (avanço). Segundo Sachs (2004), há dois principais avanços de cunho epistemológico na noção de DS. O primeiro se refere à explicitação de critérios de sustentabilidade do desenvolvimento, em suas diferentes dimensões. Apesar de ser uma noção ainda vaga (VEIGA, 2006) e da falta de consenso sobre suas dimensões e critérios (PAULISTA; VARVAKIS; MONTIBELLER-FILHO, 2008), pode-se considerar oito delas, de acordo com Sachs (2002, p. 85-88): social, cultural, ecológica, ambiental, territorial, econômico, política nacional e política internacional. O segundo avanço refere-se à reconceituação do desenvolvimento, tema do próximo tópico deste artigo.

Por fim, Chaves e Rodrigues (2006) resumem que o debate sobre DS expõe novos rumos para tratamento das questões ambientais (local/global) e explicitam as determinações políticas e econômicas subjacentes aos modelos de desenvolvimento. Além disso, a retórica do DS passou a ser utilizada por diferentes grupos como recurso de denúncia política ou exercício de cidadania, abertura de novos espaços de expressão e como bandeira para legitimidade de causas locais, nacionais e globais.

\section{Por uma nova concepção de desenvolvimento}

Decorrente da necessidade de reformulação da concepção de desenvolvimento, autores provenientes de distintas matrizes teóricas vêm elaborando propostas que rompem com os paradigmas vigentes.

Um deles é Amartya Sen, que recupera a lógica liberal smithiana de desenvolvimento e recoloca a ideia da atuação de agente livre (indivíduos) para o perfeito funcionamento dos mercados - o que resultaria, teoricamente, na transformação do interesse egoísta individual em benefícios à sociedade. Essa reintrodução do elemento social no conceito de desenvolvimento, como elaborado por Sen, é fruto também de influências dos debates a respeito da equidade, igualdade e justiça social proveniente de autores como John Rawls, por exemplo.

Para Sen (2000), a expansão da liberdade é vista como o principal fim e principal meio do desenvolvimento. Por isso, sua ideia de desenvolvimento como liberdade. Para o autor, "o desenvolvimento consiste na eliminação de privações de liberdade que limitam as escolhas e as oportunidades das pessoas de exercer ponderadamente sua condição de agente" (SEN, 2000, p. 10).

Sen explica que a expansão das liberdades que as pessoas podem vir a desfrutar é considerada segundo dois pontos de vista:

1) Como fim primordial do desenvolvimento. É o papel constitutivo do processo de desenvolvimento, relacionado "à importância da liberdade substantiva no enriquecimento da vida humana" (SEN, 2000, p. 52). As liberdades substantivas incluem capacidades elementares, como ter condições para evitar privações como a fome, desnutrição, morbidez evitável, morte prematura, assim como liberdades associadas a saber ler, escrever, fazer cálculos aritméticos, ter participação política, liberdade de expressão etc.

Sob estes aspectos, para alcançar o desenvolvimento se deve eliminar as fontes de privação destas liberdades substantivas: pobreza e tirania, carência de oportunidades econômicas e destituição social sistemática (educação, emprego remunerado, segurança econômica e social), negligência dos serviços públicos (acesso a serviços de saúde, saneamento básico, água tratada) e intolerância ou interferência excessiva de Estados repressivos.

2) Como principal meio do desenvolvimento. É o papel instrumental desse processo, concernente ao "modo como diferentes tipos de direitos, oportunidades e intitulamentos contribuem para a expansão da liberdade humana em geral e, assim, para a promoção do desenvolvimento" (SEN, 2000, p. 54). Seriam cinco liberdades instrumentais:

a) liberdades políticas: direitos civis, políticos e sociais;

b) facilidades econômicas: financiamentos e utilização de recursos econômicos com propósito para consumo, produção ou troca;

c) oportunidades sociais: saúde, educação etc., que influenciam nas liberdades substantivas;

d) garantias de transparência: dessegredo, clareza e inibição de corrupção, irresponsabilidades financeiras e transações ilícitas; 
e) segurança protetora: rede de segurança social com disposições institucionais fixas, como benefícios a desempregados, suplemento de renda a indigentes, distribuição de alimentos em crises de fome coletiva, empregos públicos de emergência para gerar renda a necessitados.

As capacidades individuais estão atreladas às inter-relações entre estas liberdades e às disposições econômicas, sociais e políticas, que, em arranjos institucionais apropriados, constituem os meios para a liberdade. Isso implica em "desenvolver e sustentar uma pluralidade de instituições, como sistemas democráticos, mecanismos legais, estruturas de mercado, provisão de serviços de educação e saúde, facilidades para mídias e outros tipos de comunicação etc." (SEN, 2000, p. 71), realizadas pela iniciativa privada, pública ou mescladas, assim como por ONGs e entidades cooperativas.

Por tais colocações, os fins e os meios do desenvolvimento colocam a liberdade como centro e não o crescimento econômico. Sob essa perspectiva, se pondera que Estado e sociedade têm papel no fortalecimento e na proteção das capacidades humanas. As pessoas, vistas como ativamente envolvidas neste processo, devem receber as oportunidades adequadas para decidir seu próprio destino.

A liberdade é central nessa reconceituação de desenvolvimento por duas razões: a) avaliatória: se há aumento das liberdades das pessoas; b) eficácia: o desenvolvimento depende da livre condição de agente das pessoas (SEN, 2000, p. 18). Sobre a condição de agente, Sen a entende como "alguém que age e ocasiona mudança e cujas realizações podem ser julgadas de acordo com seus próprios valores e objetivos, independentemente de as avaliarmos ou não também segundo algum critério externo" (SEN, 2000, p. 33).

Por essa compreensão, atenta-se à expansão das capacidades das pessoas de levar o tipo de vida que elas valorizam, tradições que querem seguir, como desejam agir, onde trabalhar, o que produzir, o que consumir etc.

Essas derradeiras proposições de Sen vêm ao encontro de algumas colocações de Antônio Carlos S. Diegues, autor cujo enfoque das ciências sociais trouxe contribuições acadêmicas e políticas significativas no cenário nacional a respeito do equilíbrio entre povos e comunidades tradicionais, planejamento ambiental e conservação da natureza. Ao se referir às Sociedades Sustentáveis como contraponto ao DS, Diegues (2001, p. 52-53) argumenta a favor de que cada sociedade seja capaz de definir seu padrão de produção e consumo, bem como o bem-estar a partir de sua cultura, de seu desenvolvimento histórico e de seu ambiente. Por essas ideias, as pessoas são agentes do desenvolvimento e não apenas objetos passivos de projetos desenvolvimentistas impostos a partir de outro contexto.

Em linha argumentativa semelhante estão as contribuições de Virgílio M. Viana, que possui suas origens nas ciências agrárias e atualmente é figura de destaque na elaboração de programas inovadores no Estado do Amazonas, envolvendo conservação da natureza, povos e comunidades tradicionais, manejo florestal e mudanças climáticas. Viana (2007) nos relembra que envolver é a antítese de des-envolver. Des-envolver significa tirar do invólucro, descobrir o que está encoberto, enquanto envolver significa manter-se num invólucro, comprometer-se. Para Viana, os paradigmas desenvolvimentistas das sociedades industriais levaram ao des-envolvimento das pessoas com seus ecossistemas e recursos naturais. $\mathrm{O}$ autor nos dá um exemplo: no Brasil, tendemos a considerar "mato" como algo ruim. E a floresta é mato. Remover o mato é caminho para o progresso e desenvolvimento. Isso se traduziu em políticas públicas, atitudes práticas, investimento público e privado. Tal compreensão refletiu-se na criação de Unidades de Conservação sem a presença humana (para preservação) e devastação para pecuária e monoculturas agrícolas (para progresso). Segundo essa concepção, a Floresta Amazônica é mais valiosa derrubada do que de pé. As populações que ali vivem, por terem uma relação diferenciada com esse ambiente, são des-envolvidas de seu contexto ambiental (em muitos casos, retiradas de seu local de morada) por meio de ações ressonantes com outra ideia de "envolvimento", que tentam encaixá-las em padrões diferentes daquele onde vivem.

Por isso, o autor fala em Envolvimento Sustentável (ES), que designa "o conjunto de políticas e ações destinadas a fortalecer o envolvimento das sociedades com os ecossistemas locais, expandindo os seus laços sociais, econômicos, culturais, espirituais e ecológicos" (VIANA, 2007, p. 43-44). A ideia de sustentabilidade permearia todas essas dimensões. Fortalecer a ideia de ES na Amazônia, por exemplo, significa valorizar os povos e comunidades tradicionais que ali vivem, respeitando seus direitos à propriedade e ao manejo tradicional dos ecossistemas. Trata-se de desenvolver estratégias de conservação da floresta por meio de tecnologias ambientalmente apropriadas e economicamente rentáveis, isto é, a floresta ser mais rentável de pé do que derrubada. É valorizar e aprimorar o sistema tradicional de manejo, para maior sustentabilidade e produ- 
tividade de produtos florestais certificados. Um dos aspectos centrais do ES é envolver essas populações nas tomadas de decisão sobre a gestão dos ecossistemas, reconhecendo seu grandioso valor na proteção da natureza feita até hoje.

De acordo com tais proposições, o desafio do ES é elaborar um conceito novo que estimule a mudança de atitude, de valores e de práticas no processo de tomada de decisões públicas e privadas. Ao mesmo tempo, deve-se respeitar, valorizar e fortalecer as estruturas organizativas das populações que vivem em determinados contextos ambientais, envolvendo-as ativamente nas etapas de planejamento, implantação e avaliação de políticas e ações governamentais (VIANA, 2007, p. 56).

Por outro lado, temos a ótica de Edgar Morin, pensador francês que parte do ecletismo entre as ciências humanas e naturais para propor novas bases epistemológicas da ciência e, com isso, configurar a teoria do pensamento complexo e/ou complexidade. Para Morin e Kern (2001), o repensar crítico do desenvolvimento requer igualmente o questionamento do que é o subdesenvolvimento. Ao se ponderar esses dois termos, inevitavelmente se recai na discussão e na valoração sobre prós e contras das diferentes culturas. Considerado de forma mais ampla, o subdesenvolvimento a ser superado é aquele mental, psíquico, afetivo e humano, que se configura como o problema-chave a ser suplantado para alcançar a "hominização", entendida como o desenvolvimento das potencialidades psíquicas, espirituais, éticas, culturais e sociais do homem (MORIN; KERN, 2001, p. 112).

Portanto, o desenvolvimento é entendido como uma finalidade, de viver verdadeiramente e viver melhor, isto é, "viver com compreensão, solidariedade, compaixão. Viver sem ser explorado, insultado, desprezado" (MORIN; KERN, 2001, p. 118). Pela defesa da hominização, os autores ponderam que deve haver uma ética do desenvolvimento, na qual a busca primordial é do viver bem e melhor. Para tanto, fazem um alerta:

Temos de considerar a insuficiência da concepção, mesmo hominizante, de desenvolvimento que, como a palavra indica, desdobra, desenrola e estende. Devemos dialetizá-la com a ideia de envolvimento e de involução, que nos remete para a origem ou antemundo, imersão nas profundezas do ser, regresso ao antigo, reiteração, esquecimento de si, introspecção quase fetal num banho amniótico beatificante, imersão na natureza, retorno aos mitos, busca sem fim, paz sem palavras (MORIN; KERN, 2001, p. 119).
Ainda na esteira da diferença entre desenvolvimento e subdesenvolvimento, Sachs (1993, p. 16-18) descreve que existe um abismo entre os países do Norte, tidos como desenvolvidos, e os do Sul, considerados subdesenvolvidos ou em desenvolvimento, que do aspecto econômico se generaliza para âmbitos mais amplos. Seguindo esse ponto de vista, Morin e Kern apontam que "o subdesenvolvimento dos desenvolvidos aumenta precisamente com seu desenvolvimento técnico-econômico" (MORIN; KERN, 2001, p. 115). Dito de outra forma, os padrões insustentáveis de produção e consumo, expressos segundo modelos culturais universalizados a partir dos países do Norte, são os que fortemente contribuíram para a emergência da crise socioambiental na atualidade e marcadamente são mais representativos do modelo da racionalidade moderna ocidental. Por isso, a necessidade de reconfiguração dos padrões culturais circulantes na esfera global, como evidenciado por Santos (2008). Esse é um dos motivos pelo qual Santos menciona a defesa do multiculturalismo e da pluralidade epistemológica, pois se deve reconfigurar o que é o desenvolvimento a partir da compreensão vinda de diferentes culturas e, em última instância, para o ser humano de forma mais ampla - e não reduzida a apenas uma ou outra dimensão de sua existência.

Também Morin e Kern (2001) mostram que, mais além do que buscar a chave para o desenvolvimento-problema, é preciso recuperar o sentido do desenvolvimento humano. Pelo crivo da hominização, o desenvolvimento é colocado para além da ótica do crescimento, mas concebido de maneira antropológica e compreendido segundo sua multidimensionalidade, para "ultrapassar ou quebrar os esquemas não só econômicos, mas também civilizacionais e culturais ocidentais que pretendem fixar o seu sentido e as suas normas. Deve romper com a concepção do progresso como certeza histórica" (MORIN; KERN, 2001, p. 112-113).

Outra abordagem de desenvolvimento nos é dada por Ignacy Sachs, economista e sociólogo com influências estruturalistas e desenvolvimentistas, que construiu sua obra a partir da integração de reflexões sociais, econômicas e ambientais, especialmente pelo ponto de vista dos países em desenvolvimento. De acordo com Sachs (2002, p. 65),

[...] o desenvolvimento é o processo histórico de apropriação universal pelos povos da totalidade dos direitos humanos, individuais e coletivos, negativos (liberdade contra) e positivos (liberdade a favor), significando três 
gerações de direitos: políticos, cívicos e civis; sociais, econômicos e culturais; e os direitos coletivos ao desenvolvimento, meio ambiente e à cidade.

Para o autor, o crescimento econômico serve como expansão das forças produtivas da sociedade para alcançar esses direitos plenos para toda população. Por essa compreensão, pondera-se um triplo imperativo ético: solidariedade sincrônica (com as gerações presentes), diacrônica (com as futuras) e com a inviolabilidade da natureza (respeito à biodiversidade, à diversidade cultural e à sustentação da vida). Isso significa que a conservação da natureza entra necessariamente em cena ao se refletir sobre o futuro da humanidade e sobre o alcance de direitos plenos. Sobre a conservação, Sachs (2002, p. 68-71) aponta que a natureza sem pessoas é uma violação dos direitos à vida, relembrando estudos que mostram que a natureza habitada é enriquecida pela presença humana.

Mais além, deve-se desenvolver uma economia da permanência, pautada na perenidade dos recursos e no aproveitamento sensato da natureza, isto é, na utilização da ciência e da tecnologia para transformar elementos do ambiente em recursos (um conceito cultural e histórico), sem destruir o meio. Para que seja possível chegar à harmonização entre estes objetivos sociais, ecológicos e econômicos em áreas estratégicas, como a Amazônia, necessita-se reconhecer o direito das populações locais em utilizar os recursos naturais, dando-lhes papel central no planejamento da proteção e do monitoramento de seu ambiente, por meio:

a) da aliança de conhecimentos tradicionais com os da ciência moderna;

b) da identificação, criação e desenvolvimento de alternativas no uso de recursos de biomassa e geração de renda;

c) do envolvimento dos agentes locais em planejamento participativo;

d) do cultivo da conscientização do valor e da necessidade de proteção da área, bem como de padrões de crescimento local apropriado.

Esse modo de compreender o desenvolvimento, segundo Sachs (2002, p. 75-76), implica numa abordagem negociada e contratual dos recursos entre os diferentes atores envolvidos, com seus interesses particulares, mas tendo em vista os objetivos mencionados acima. Por meio desse processo de negociação, explora-se a matriz ecossistema/ cultura, valorizam-se respostas culturais para desafios ambientais, aproveita-se o sistema tradicional de manejo dos recursos naturais, usufrui-se da melhor maneira a biodiversidade e identificam-se as necessidades fundamentais para a melhoria da qualidade de vida dos envolvidos. Segundo o autor, esse pode ser um caminho alternativo para regimes democráticos, enquanto resposta criativa à atual crise de paradigmas: colapso do socialismo real, enfraquecimento do estado do bem-estar, não cumprimento das promessas da contrarrevolução neoliberal.

Em outro modo de argumentar, Sachs (2002, p. 2942) fala em uma nova civilização fundamentada no aproveitamento sustentável dos recursos naturais. Para termos a "moderna civilização baseada em biomassa", deve-se inicialmente transformar os conhecimentos das "pessoas dos ecossistemas" (povos e comunidades tradicionais), que possuem conhecimentos profundos sobre a natureza, e decodificá-los pelas etnociências, de modo a conjugá-los com as ciências de ponta. Além disso, explorar o paradigma do "B ao cubo": biodiversidade, biomassa, biotecnologia.

A) A biodiversidade envolve o estudo de espécies e genes, de ecossistemas e paisagens e da diversidade cultural no processo histórico de coevolução. Para tanto, é necessária uma abordagem holística e interdisciplinar, que conjugue ciências sociais e naturais para a conservação e uso/aproveitamento racional da natureza.

B) A biomassa coletada ou produzida em terra e na água refere-se aos 5-F: alimento (food), suprimentos (feed - ou matérias-primas industriais, como fibras, celuloses, óleos, resinas etc.), combustível (fuel - os biocombustíveis), fertilizantes (fertilizers) e ração animal industrializada (feedstock). Sachs (2004, p. 130) adiciona mais três elementos posteriormente: materiais de construção, fármacos e cosméticos. O uso da biomassa pode ser otimizado quando combinado de maneira adequada em sistemas integrados de alimento-energia adaptados às diferentes condições agroclimáticas e socioeconômicas. Busca-se cada vez mais, por meio da ciência, desenvolver sistemas produtivos artificiais análogos aos ecossistemas naturais.

C) A biotecnologia tem papel fundamental, por propiciar o aumento da produtividade da biomassa e permitir a expansão de produtos dela derivados. Para tanto, é primordial disponibilizar a biotecnologia moderna aos pequenos produtores, implementar políticas complementares (acesso justo à terra, ao conhecimento, ao crédito e mercado, melhor educação rural) e desenvolvimento de uma "química verde" (para substituir a petroquímica e trocar combustível fóssil por biocombustível). 
Segundo o autor, atualmente já se consideram países com clima tropical como mais vantajosos do que os temperados, por permitir produtividades maiores de biomassa. O Brasil tem boas condições de "pular etapas" - aquelas percorridas pelos países industrializados - e chegar à moderna civilização da biomassa, por combinar algumas vantagens competitivas: recursos naturais abundantes e baratos, fronteira agrícola ainda não totalmente explorada, força de trabalho qualificada e conhecimentos modernos. Para tanto, necessita-se chegar a linhas de ação para o aproveitamento racional da natureza, ordenadas segundo prioridades em ciência e tecnologia e que criem estratégias de sustentabilidade rumo a essa sociedade proposta.

No caso da Amazônia, Sachs (2002, p. 38-42) sugere 10 prioridades de pesquisa para alcançar esse objetivo:

1) compreender melhor o funcionamento dos ecossistemas;

2) pesquisas com macrodados e dados locais sobre a biodiversidade, sob controle de mãos nativas;

3) aliança entre cientistas sociais e naturais para estudar a diversidade biológica e cultural;

4) uso sustentável da biodiversidade e pesquisas avançadas sobre ela;

5) estudos de sistemas integrados de produção (da agricultura familiar aos grandes sistemas comerciais), adaptados às condições locais;

6) logística adequada para produtos florestais (armazenamento, transporte e processamento);

7) diferentes sistemas locais de geração de energia (baseados na biomassa, mini-hidrelétricas, eólico, solar);

8) fortalecimento e modernização das técnicas de subsistência da agricultura familiar;

9) acoplar novos sistemas de produção (como a piscicultura, domesticação de animais etc.);

10) redimensionamento de acesso a bens e serviços sociais apropriados às condições específicas da Amazônia rural.

O acento dado por Sachs é a busca de padrões endógenos de desenvolvimento, que sejam mais justos socialmente e que respeitem a natureza. Por fim, Sachs (2004) resume suas ideias, influenciado também pelas dos autores acima citados, no que chama de estratégias de desenvolvimento nacionais includentes, sustentáveis e sustentadas (DISS), cujo "adjetivo sustentável se refere à condicionalidade ambiental, $[\ldots]$ sustentado se refere à permanência do processo de desenvolvimento" (SACHS, 2004, p. 70) e includente se refere à dimensão social.

O DISS está em oposição ao crescimento perverso: excludente (do mercado de consumo), concentrador (de ren- da e riqueza), em mercados de trabalho segmentados (que mantêm uma parte da população na economia informal), em condições precárias de subsistência pela agricultura familiar e de fraco ou nulo estímulo à participação política. Por outro lado, o DISS se refere ao tratamento desigual aos desiguais, ao comércio justo, à transformação da ciência e da tecnologia em bens públicos, ao exercício pleno dos direitos humanos e à democracia participativa e planejamento local participativo. Também fazem parte dessas proposições o acesso a programas de assistência, políticas sociais compensatórias e serviços públicos (educação, saúde, moradia etc.), a facilitação de crédito, a geração de empregos e o trabalho decente para todos. Este último significa a saída do mercado informal e a montagem de microempresas, o estímulo ao trabalho autônomo e ao empreendedorismo, bem como o estímulo e a modernização da produção agrícola familiar/ rural (SACHS, 2004, p. 38-42).

\section{Conclusão}

Como pudemos argumentar, as metas do desenvolvimento não são apenas o crescimento econômico, entendido como uma condição necessária, mas não suficiente. As metas dizem respeito a termos uma vida melhor, mais feliz e mais completa para todos em âmbito local/global. Nesse sentido, o desenvolvimento é a apropriação plena dos direitos humanos e implica em igualdade, equidade e solidariedade.

De acordo com Sachs (2004, p. 26), neste momento o grande desafio das teorias desenvolvimentistas é encontrar soluções para dois grandes problemas enfrentados pela humanidade: desemprego em massa e desigualdade crescente. Sob essa perspectiva, o crescimento econômico deve ser guiado para ampliar o emprego, reduzir a pobreza, atenuar a desigualdade e evitar as armadilhas da competitividade espúria (SACHS, 2004, p. 14).

A equidade significa, então, "o tratamento desigual dispensado aos desiguais, de forma que as regras do jogo favoreçam os participantes mais fracos e incluam ações afirmativas que os apoiem" (SACHS, 2004, p. 14). Uma das ideias de Sachs para aliar a necessidade de crescimento econômico com equidade é a do desenvolvimento endógeno (oposto ao crescimento mimético), que envolve: autoconfiança (oposta à dependência), orientação por necessidades (em oposição à orientação pelo mercado), harmonia com a natureza, abertura à mudança institucional. 
O autor coloca que, para executar o DISS e fortalecer esse processo endógeno, necessita-se aliar um projeto societal para urgências não apenas no curto, mas também médio e longo prazos. Deve haver crescimento baseado na mobilização de recursos internos, induzido pelo emprego. Também é importante envolver todos os agentes nos processos de negociação: autoridades públicas, trabalhadores, empregadores e sociedade civil organizada (o que inclui o Terceiro Setor). E, por fim, combinar políticas complementares de crescimento induzido por empregos sem importações, consolidação e modernização da agricultura familiar, ações afirmativas para melhorar as condições de criação e gestão de empreendimentos próprios e fortalecimento das estratégias endógenas nacionais, que, ao obterem maior sucesso, adquirem poder de barganha, no plano internacional, para mudanças da ordem econômica desigual.

A necessidade de se reformular a ideia de desenvolvimento é torná-la mais central e operacional, reaproximando ética, economia e política na condução de uma sociedade mais includente socialmente, sustentável ecologicamente e sustentada economicamente. Por essa nova concepção de desenvolvimento, pretende-se

[...] habilitar cada ser humano a manifestar potencialidades, talentos e imaginação, na procura da autorrealização e da felicidade, mediante empreendimentos individuais e coletivos, numa combinação de trabalho autônomo e heterônomo e de tempo dedicado a atividades não produtivas (SACHS, 2004, p. 35).

\section{Referências}

ALLEN, R. How to save the world: Strategy for world conservation. London: Kogan Page, 1980.

BANERJEE, S. B. Quem sustenta o desenvolvimento de quem? O desenvolvimento sustentável e a reinvenção da natureza. In: FERNANDES, M.; GUERRA, L. (Orgs.). Contradiscurso do desenvolvimento sustentável. 2. ed. rev. Belém: UNAMAZ; NAEA-UFPA, 2006.

BARBIERI, J. C. Desenvolvimento e meio ambiente: as estratégias de mudanças da Agenda 21. 7. ed. rev. e atual. Petrópolis: Vozes, 2005.

BARNEY, G. O. (Org.). The Global 2000 Report to the President. v. I: Entering the Twenty-First Century. v. II: The
Em suma, algumas chaves foram colocadas para se alcançar essas metas: 1) busca do exercício pleno dos direitos humanos; 2) expansão das liberdades substantivas e instrumentais; 3) conhecimento mais aprofundado da biodiversidade, na sua relação com a diversidade cultural; 4) uso sustentável da biomassa; 5) planejamento participativo, dialógico e negociado entre os atores envolvidos, em arranjos contratuais que beneficiem a todos; 6) envolvimento das populações enquanto agentes em áreas a serem conservadas; 7) maximização de oportunidades que criem condições de produção de meios de existência viáveis e em função de cada contexto socioambiental.

Por fim, compartilhamos com Sachs (1993) a opinião de que atingiremos o objetivo de proporcionar a todos uma sobrevivência decente, em um planeta para sempre habitável, no momento em que se reconhecer que devemos modificar os comportamentos econômica, ambiental e socialmente destrutivos. Isso requer mais do que estratégias de desenvolvimento de uma agenda em longo prazo. Requer a reconfiguração de padrões de produção compatíveis com a equidade social e prudência ambiental, um novo conceito de modernidade e uma nova civilização, fundada nas ideias de respeito humano, conhecimento intensivo e amor à natureza. Como aponta Sachs (1993, p. 17), "a verdadeira escolha não é entre desenvolvimento e meio ambiente, mas entre formas de desenvolvimento sensíveis ou insensíveis à questão ambiental". Necessitamos contribuir com a reformulação dos modelos vigentes, que cindem políticas ambientais e as econômico-sociais, para sermos capazes de discutir em pé de igualdade sobre um desenvolvimento humano verdadeiramente sustentável.

Technical Report. Washington: U.S. Government Printing Office, 1980.

BRANDT, W. ICIDI. North-South - a programme for survival: report of the Independent Commission on International Development Issues under the chairmanship of Willy Brandt. Massachusetts: MIT Press, 1980.

Common crisis north-south: cooperation for world recovery. Massachusetts: MIT Press, 1983. Disponível em: $<$ http://files.globalmarshallplan.org/inhalt/coc_2.pdf $>$. Acesso em: 04/2011.

BRITO, D. C. A paradoxal unidade do discurso de desenvolvimento. In: ALTVATER, E. et al. Terra incógnita: reflexões 
sobre globalização e desenvolvimento. Belém: UFPA/NAEA, 1999.

BURY, J. B. The idea of progress: an inquiry into its origin and growth. London: Macmillan and Co., 1921.

CARVALHO, D. F. Desenvolvimento Sustentável e seus limites teórico-metodológicos. In: FERNANDES, M.; GUERRA, L. (Orgs.). Contradiscurso do desenvolvimento sustentável. 2. ed. rev. Belém: UNAMAZ; NAEA-UFPA, 2006.

CAVALCANTI, C. Em busca da compatibilização entre a ciência da economia e a ecologia: bases da economia ecológica. In: VIEIRA, P. F.; MAIMON, D. (Orgs.). As ciências sociais e a questão ambiental: rumo à interdisciplinaridade. Rio de Janeiro: APED; Belém: NAEA/UFPA, 1993.

CERQUEIRA, F.; FACCHINA, M. A Agenda 21 e os objetivos do milênio: as oportunidades para o nível local.Brasília: MMA; Secretaria de Políticas para o Desenvolvimento Sustentável, 2005. Caderno de Debate: Agenda 21 e Sustentabilidade, n. 7. Disponível em: <http://www.pnud.org.br/odm/\#>. Acesso em: 04/2011.

CHAVES, M. P. S. R.; RODRIGUES, D. C. B. Desenvolvimento sustentável: limites e perspectivas no debate contemporâneo. INTERAÇÕES: Revista Internacional de Desenvolvimento Local, Campo Grande: Universidade Católica Dom Bosco, v. 8, n. 13, p. 99-106, 2006.

et al. Recursos naturais, biotecnologia e conhecimentos tradicionais: questões sobre o desenvolvimento sustentável na Amazônia. Revista Perspectiva, Erechim: URI, v. 32, n. 117, p. 137-148, 2008.

COMISSÃO MUNDIAL SOBRE MEIO AMBIENTE E DESENVOLVIMENTO (CMMAD). Nosso futuro comum. 2. ed. Rio de Janeiro: Editora FGV, 1991.

DIEGUES, A. C. S. Ecologia humana e planejamento em áreas costeiras. 2. ed. São Paulo: NUPAUB/USP, 2001.

O mito moderno da natureza intocada. 5. ed. São Paulo: Hucitec; NUPAUB/USP, 2004.

DUTRA, M. S. Biodiversidade e desenvolvimento sustentável: considerações sobre um discurso de inferiorização dos povos da floresta. In: FERNANDES, M.; GUERRA, L. (Orgs.). Contradiscurso do desenvolvimento sustentável. 2. ed. rev. Belém: UNAMAZ; NAEA-UFPA, 2006.

FAZENDA, I. C. A. Interdisciplinaridade: história, teoria e pesquisa. 14. ed. Campinas: Papirus, 2007.
Interdisciplinaridade-transdisciplinaridade: visões culturais e epistemológicas. In: disciplinaridade? São Paulo: Cortez, 2008. (Org.). O que é inter-

FERNANDES, M. Desenvolvimento Sustentável: antinomias de um conceito. In: ; GUERRA, L. (Orgs.). Contradiscurso do desenvolvimento sustentável. 2. ed. rev. Belém: UNAMAZ; NAEA-UFPA, 2006.

FOSTER, J. B. A ecologia de Marx: materialismo e natureza. Rio de Janeiro: Civilização brasileira, 2005.

GODARD, O. O desenvolvimento sustentável: paisagem intelectual. In: CASTRO, E.; PINTON, F. (Orgs.). Faces do trópico úmido: conceitos e questões sobre desenvolvimento e meio ambiente. Belém: Cejup: NAEA-UFPA, 1997.

A gestão integrada dos recursos naturais e do meio ambiente: conceitos, instituições e desafios de legitimação. In: VIEIRA, P. F.; WEBER, J. (Orgs.). Gestão de recursos naturais renováveis e desenvolvimento: novos desafios para a pesquisa ambiental. 3. ed. São Paulo: Cortez, 2002.

INSTITUTO BRASILEIRO DO MEIO AMBIENTE E DOS RECURSOS NATURAIS RENOVÁVEIS (IBAMA) E UNIVERSIDADE LIVRE DA MATAATLÂNTICA(UMA). Perspectivas do Meio Ambiente Mundial - 2002 GEO-3: Passado, presente e futuro. Tradução de Sofia Shellard e Neila Barbosa Corrêa. Brasília: IBAMA; Salvador: UMA. 2004. Disponível em: <http://www.wwiuma.org.br/geo_mundial_arquivos/ index.htm>. Acesso em: 04/2011.

JAPIASSU, H. O sonho transdisciplinar e as razões da filosofia. Rio de Janeiro: Imago, 2006.

LANDES, D. S. Prometeu desacorrentado: transformação tecnológica e desenvolvimento industrial na Europa ocidental, desde 1750 até a nossa época. Tradução de Vera Ribeiro. Rio de Janeiro: Nova Fronteira, 1994.

LEFF, E. Epistemologia ambiental. São Paulo: Cortez, 2002.

Racionalidade ambiental e reapropriação social da natureza. Tradução de Luís Carlos Cabral. Rio de Janeiro: Civilização Brasileira, 2006.

MAIMON, D. A economia e a problemática ambiental. In: VIEIRA, P. F.; MAIOMON, D. (Orgs.). As ciências sociais e a questão ambiental: rumo à interdisciplinaridade. Rio de Janeiro: APED; Belém: NAEA-UFPA, 1993.

MARIN, R. A.; CASTRO, E. M. R. Prefácio 2. ed. In: FERNANDES, M.; GUERRA, L. (Orgs.). Contradiscurso do desenvolvimento sustentável. 2. ed. rev. Belém: UNAMAZ; NAEA-UFPA, 2006. 
MEADOWS, D. L. et al. Limites do crescimento: um relatório para o projeto do clube de Roma sobre um dilema da humanidade. 2. ed. São Paulo: Perspectiva, 1978.

MEUNIER, O.; FREITAS, M. Culturas, técnicas, educação e ambiente: uma abordagem histórica do desenvolvimento sustentável. In: (Org.). Amazônia: a natureza dos problemas e os problemas da natureza. Manaus: EDUA, 2005.

MONTIBELLER-FILHO, G. O mito do desenvolvimento sustentável: meio ambiente e custos sociais no moderno sistema produtor de mercadorias. 2. ed. Florianópolis: Ed. UFSC, 2004.

MORIN, E. Os sete saberes necessários à educação do futuro. São Paulo: Cortez; Brasília: UNESCO, 2000.

Ciência com consciência. Tradução de Maria D. Alexandre e Maria Alice Sampaio Dória. Ed. rev. modificada pelo autor. 11. ed. Rio de Janeiro: Bertrand Brasil, 2008.

Piaget, 2001.

; KERN, A. B. Terra/Pátria. 2. ed. Lisboa: Instituto

NISBET, R. A. História da ideia de progresso. Tradução de Leopoldo José Collor Jobim. Brasília: Editora UnB, 1985.

NOGUEIRA, M. G.; CHAVES, M. P. S. R. Desenvolvimento sustentável e ecodesenvolvimento: uma reflexão sobre as diferenças ideopolíticas conceituais. Somanlu: Revista de Estudos Amazônicos, Manaus: EDUA/CAPES, v. 5, n. 1, p. 129-143, jan./jun. 2005.

PAULISTA, G.; VARVAKIS, G.; MONTIBELLER-FILHO, G. Espaço emocional e indicadores de sustentabilidade. Ambiente e Sociedade, Campinas, v. 11, n. 1, p. 185-200, jan.-jul. 2008.

REDCLIFT, M. Os novos discursos de sustentabilidade. In: FERNANDES, M.; GUERRA, L. (Orgs.). Contradiscurso do desenvolvimento sustentável. 2. ed. rev. Belém: UNAMAZ; NAEA-UFPA, 2006.

SACHS, I. Estratégias de transição para o século XXI: desenvolvimento e meio ambiente. São Paulo: Studio Nobel: Fundap, 1993.

. O desenvolvimento enquanto apropriação dos direitos humanos. Estudos Avançados, São Paulo, v. 12, n. 33, maio/ ago. 1998. Disponível em: <http://www.scielo.br/scielo. php?pid=S0103-40141998000200011\&script $=$ sci_arttext $>$. Acesso em: 04/2011.

Caminhos para o desenvolvimento sustentável. Rio de Janeiro: Garamond, 2002.

. Desenvolvimento: includente, sustentável, sustentado. Rio de Janeiro: Garamond, 2004.

SANTOS, B. S. A gramática do tempo: para uma nova cultura política. São Paulo: Cortez, 2008.

SEN, A. K. Desenvolvimento como liberdade. Tradução de Laura Teixeira Motta. São Paulo: Companhia das Letras, 2000.

SILVA, M. A. Introdução à economia ecológica (a economia na perspectiva ecológica). Minicurso - $61^{\mathrm{a}}$ Reunião Anual da Sociedade Brasileira para o Progresso da Ciência, Manaus, UFAM, 2009

VEIGA, J. E. Desenvolvimento sustentável: o desafio do século XXI. 2. ed. Rio de Janeiro: Garamond, 2006.

VIANA, V. M. As florestas e o DESenvolvimento sustentável na Amazônia. 2. ed. Manaus: EditoraValer, 2007.

WHAT NOW - another development. The 1975 Dag Hammarskjšld Report. Development Dialog, n. 1/2, 1975. Disponível em: < http://www.dhf.uu.se >. Acesso em: 04/2011.

Recebido em maio de 2011.

Aceito em agosto de 2011. Publicado em dezembro de 2011. 